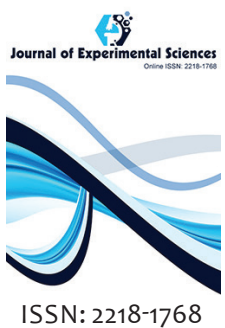

Received: February 22, 2018 Accepted: May 01, 2018 Published: May 11, 2018

*Corresponding Author: Sharif Ahmed

Email:s.ahmed@irri.org

\section{Performance of aus rice in different tillage systems and crop establishment method in Southwest Bangladesh}

\author{
Latiful Bari', Sharif Ahmed²* \\ 'Specialist-Postharvest, International Rice Research Institute, Bangladesh office, ${ }^{2}$ Specialist-Agricultural Research \\ and development, International Rice Research Institute, Bangladesh office
}

\begin{abstract}
High labor wage and irrigation water scarcity are the major constraints to becoming rice production less profitable and unsustainable in Bangladesh. To address these problems, rice production needed less water and less labor consuming production technologies. In traditional rice production systems which is puddled-transplanted rice (PTR), a significant amount of water and labor are used for tillage (wet) and transplanting operations.A farmers' participatory on-farm trial was conducted to evaluate the performance of aus rice at different tillage systems and crop establishment methods in the southern part of Bangladesh. Wet tillage (puddled systems) to dry-tillage and transplanted rice to direct dry-seeded rice (DSR) may have the potential to reduce production cost by using less labor and water, resulting in higher profit. The trial examined tillage systems (strip tillage, reduced tillage and puddling) and crop establishment methods (direct dry-seeded and transplanted) in six farmers' fields in aus 2015. Crop established by reduced- and strip-tillage in DSR conditions reduced crop duration by 7 days compared to PTR. Grain yield (4.4-4.6 $\left.\mathrm{tha}^{-1}\right)$ was similar in DSR which is established by reduced- and strip-tillage conditions and PTR; however, total production cost in DSR was 15-18\% lower than the PTR. Slightly higher but significantly similar gross income was recorded in PTR than DSR, however, net profit was significantly lower in PTR and it was due to higher production cost involvement. DSR has the potentiality of similar yield to PTR and reduces production cost which increases the net profit of rice production.
\end{abstract}

KEYWORDs: Agricultural mechanization, dry-seeded rice, strip-tillage, reduced-tillage, aus rice.

\section{INTRODUCTION}

Rising costs of labor, high water, and energy required for puddled transplanted rice coupled with labor scarcity during the peak period of activity are the compelling factors to seek an alternate rice production method. Direct seeding of rice is an alternative to transplanted rice that could reduce the labor requirements for crop establishment and the demand for irrigation water [1,2]. Direct seeded rice can be established either dry-seeded or wet-seeded, however, dry-seeding is becoming popular among the farmers of many Asian countries because of this systems is conducive to mechanization $[3,4]$. In this systems, the crop can be established either zero tillage or strip tillage or full dry tillage (conventional) which support the principle of conservation agriculture (CA). The CA practices are now well established in different developed countries; however, not to popularize in Bangladesh yet.

Cropping systems of Bangladesh is highly intensified especially in the south-west and North-west part of the country where rice (aman) is the main crop in the wet season and a number of non-rice (rabi) or rice (boro) crops in the dry season $[2,5]$.
Bangladesh agriculture is predominant in rice-based and boro is the major rice crops due to higher yield potentiality and less risky compared to wet-season rice (aman) [6]. Last few years boro areas of some regions especially High-Ganges River Floodplains (south-west) and Barind Tracts (North-west) are decreasing because of water and labor scarcity. In these areas, diversifying cropping and production systems with low water-demanding crops is needed during boro [7]. For example, replacing boro rice with less water-demanding crops would save groundwater, but could reduce the total volume of rice production. A shortage of total rice production could be minimized by increasing the areas of aus. In south-west Bangladesh where Maize is the dominant crop in rabi and farmers commonly practice aus riceMaize sequence there but aus rice is mostly transplanted. We assumed that the practice of direct dry-seeded rice instead of puddled-transplanted rice, crop establishment not only reduce the water use in rice farming but also reduces the production cost and increases the profitability. Therefore, the on-farm trial was conducted to evaluate the performance of aus rice at different tillage systems and crop establishment methods in the southern part of Bangladesh.

Copyright: $\odot 2018$ The authors. This article is open access and licensed under the terms of the Creative Commons Attribution License (http://creativecommons.org/licenses/by/4.0/) which permits unrestricted, use, distribution and reproduction in any medium, or format for any purpose, even commercially provided the work is properly cited. Attribution - You must give appropriate credit, provide a link to the license, and indicate if changes were made. 


\section{MATERIALS AND METHODS}

\section{Experimental Sites and Seasons}

On-farm trials were conducted during aus 2015 at Borai Village in Jhenaidah Sadar Upazila of Jhenaidah District, and Subdia Village in Chuadanga Sadara Upazila of Chuadanga District in Bangladesh. The experimental sites belong to the agro-ecological zone number 11 known as the High Ganges River Floodplain, a region of relatively high land not subject to flooding. The climate of the area is subtropical, with average annual rainfall of $1450 \mathrm{~mm}$, 90\% of which falls from June to October. The temperature during the aus season is favorable for rice production, with mean monthly minimum and maximum temperatures of around 25 and $35^{\circ} \mathrm{C}$, respectively. The soils of the experimental fields at $0-15-\mathrm{cm}$ depth were sandy loam in texture, with a bulk density of $1.56-1.61 \mathrm{Mg} \mathrm{m}^{-3}$, $\mathrm{pH}$ of 7.55-7.82. Rice was grown with partial irrigation in the pre-monsoon season (April-July) is known as the aus rice. The experimental site had the history of Maize-Transplanted Aus- short time vegetables or fallow cropping systems.

\section{Experimental Design And Treatments}

The study was conducted in six farmers' fields in a randomized complete block design.

\section{Puddled Transplanted Rice (PTR)}

Transplanting of 20-25 days old seedlings from the nursery into the puddled field. Two to three seedlings per hill were transplanted manually on the puddled soil. The line to line distance was $20 \mathrm{~cm}$ but the hill to hill was random.

\section{Reduce Tillage Dsr (RT-DSR)}

Reduce tillage was done a power tiller with a seedbox and sowing tynes attached, enabling tillage and sowing in a single pass; the whole soil surface is tilled to a depth of 2-4 cm; tillage did under dry to moist soil conditions; powered by a 2-wheel tractor.

\section{Strip Tillage DSR (ST-DSR)}

Strip tillage was done as for conventional tillage, except that all the tynes are removed from the tiller except for those immediately in front of the sowing tynes; only a narrow strip of the soil surface, about $3-5 \mathrm{~cm}$ wide, is tilled to a depth of $2-4 \mathrm{~cm}$.

\section{Land Preparation, Crop Establishment, and Management}

Selected each field was divided into three equal plots and two plots were used for DSR (RT-DSR and ST-DSR) and one for PTR.

\section{DSR}

A non-selective herbicide glyphosate (Round up $31 \mathrm{ha}^{-1}$ ) was sprayed one week before sowing RT-DSR and ST-DSR to kill the weeds. DSR crop was sown using certified seeds of high-yielding cultivars BRRI dhan48 (110d duration). Fertilizer except urea was applied immediately before sowing for DSR at the rate of
20, 45, 12, and $1.5 \mathrm{~kg} \mathrm{ha}^{-1}$ of PK, S, and Zn in the forms of triple superphosphate (TSP), muriate of potash (MoP), gypsum, and zinc sulphate, respectively. Nitrogen in the form of urea was applied at the rate of $110 \mathrm{~kg} \mathrm{ha}^{-1}$ in four splits [20\% at 14 days after sowing (DAS), 30\% at 28-32 DAS, $30 \%$ at 45 DAS, and $20 \%$ at 60-65 DAS]. A power tiller seed drill (2BG-6A model, China) was used to plant dry rice seeds at a row spacing of $20 \mathrm{~cm}$ and seed rate of $45 \mathrm{~kg} \mathrm{ha}^{-1}$. The field was irrigated immediately after sowing and thereafter irrigation was based on when hair line crack appeared in the field. At each irrigation time, water was applied until its height on the soil surface reached $2-3 \mathrm{~cm}$. Plots were kept weed-free by applying the pre-emergence herbicide pendimethalin at $1000 \mathrm{~g}$ ai ha-1 at 2 DAS followed by two hands weeding at 20-25 and 40-45 DAS, respectively. The herbicide was applied at $450 \mathrm{~L}$ solution ha-1 using a knapsack-sprayer with a boom with three flat-fan nozzles.

\section{PTR}

Land preparation in PTR plots was done with 2-3 passes by a power tiller followed by laddering prior to transplanting. Fertilizer except urea was applied before final land preparation at the same rate used for DSR. Seedlings were raised in a nursery bed following improved methods recommended by BRRI (BRRI, 2013). Twenty to twenty-five days old seedlings were used for transplanting with two to three seedlings per hill at a row spacing of $20 \mathrm{~cm}$ but the plant to plant was random (common practices by farmers). After transplanting standing water was always kept in the plots by applying 5 -cm water at each irrigation which continued until the hard dough stage. Nitrogen fertilizer was applied at the rate of $110 \mathrm{~kg} \mathrm{ha}^{-1}$ in three splits [30\% at 7-10 days after transplanting (DAT), 40\% at 25-28 DAT, and 30\% at 40-45 DAT]. Two manual weeding was done at $15-20$ and 40-45 DAT, respectively.

\section{Observations}

Rice plant density was determined 15 DAS by counting the number of plants in four randomly selected $1 \mathrm{~m}$ lengths of a row in each subplot. The date of $50 \%$ anthesis was determined by daily counts of the number of panicles. The date of physiological maturity (PM) was the date when about $80 \%$ of the grains had turned a yellow-golden colour. The crop was harvested when most of the leaves had senesced.

Rice grain yield was determined by harvesting a $3 \mathrm{~m} \times 2 \mathrm{~m}$ area ( 2 spots) in the center of each treatment plot. Grain yield was converted to $\mathrm{ha}^{-1}$ at $14 \%$ moisture content.

The number of irrigation and labor for weeding in different treatment plots was recorded.

\section{Economic Analysis}

Economic analysis was done as per the standard methods $[18,19]$.

\section{Statistical Analysis}

Data were analyzed using ANOVA to evaluate differences between treatments, and the means were separated using least 
significant differences (LSD) at the $5 \%$ level of significance (Crop Stat 7.2; International Rice Research Institute, Philippines).

\section{RESULTS AND DISCUSSIONS}

\section{Crop Duration}

Crop duration significantly affected by tillage systems and crop establishment methods (Figure 1). The highest duration (116 days) required for the crop establishment method PTR. DSR established by reduced and strip-tillage had significantly lower crop duration (7 days) than PTR. In DSR condition, crop duration reduced by 3-14 days was reported from many previous studies $[1,2]$. The main reason for the reduce crop duration in DSR condition than PTR condition is lack of transplanting shock which rice seedling usually face in transplanted condition. Rice usually take 5-10 days to overcome the transplanting shocked when transplant from nursery bed to the main field.

\section{Grain Yield}

The highest grain yield (4.6 t/ha) was recorded from the crop establishment method of PTR. Slightly lower but significantly similar grain yield was recorded from the reduced and strip tillage DSR (Figure 2). From many previous studies, it is found that yield of DSR and PTR almost similar if managed well $[8,9]$ lower yield was also recorded from many previous studies where weeds were not managed well $[10,11]$. Some studies in DSR reported higher yield in strip tillage condition than reduced tillage where weed pressure was very low [2]. However, under high weed pressure situation, reduced tillage recorded higher yield than the strip tillage $[12,13]$.

\section{Economics}

Production cost was significantly affected by crop establishment method (Figure 3). The highest production cost was involved with the PTR which was $15-18 \%$ higher than the DSR. The higher production cost in PTR than DSR was mainly due to land preparation, transplanting and higher irrigation cost in PTR than DSR. Weed management cost for DSR was higher than the PTR (data not presented). It was reported from the many previous studies that production cost of DSR is lower than the PTR [1417]. The production cost of reduced and strip tillage was similar in our study which supports the findings of Alam et al. [1) in similar types of environment. Slightly higher gross income was recorded from the PTR method; however, it was significantly similar to DSR method (Figure 4). Slightly higher gross income in PTR was related to slightly higher grain and straw yield. The net profit was highest for strip tillage DSR (Figure 5). Compared with the strip-tillage DSR, reduced tillage DSR had slightly lower but significantly similar net profit. Net income of PTR was significantly lower than both strip and reduced tillage DSR. Although in DSR had slightly lower gross income than PTR; however, net profit in PTR was lower due to higher production cost involvement.

\section{CONCLUSIONS}

Both reduced and strip tillage have the potentiality to reduce production cost, resulting in higher net profit and appears to

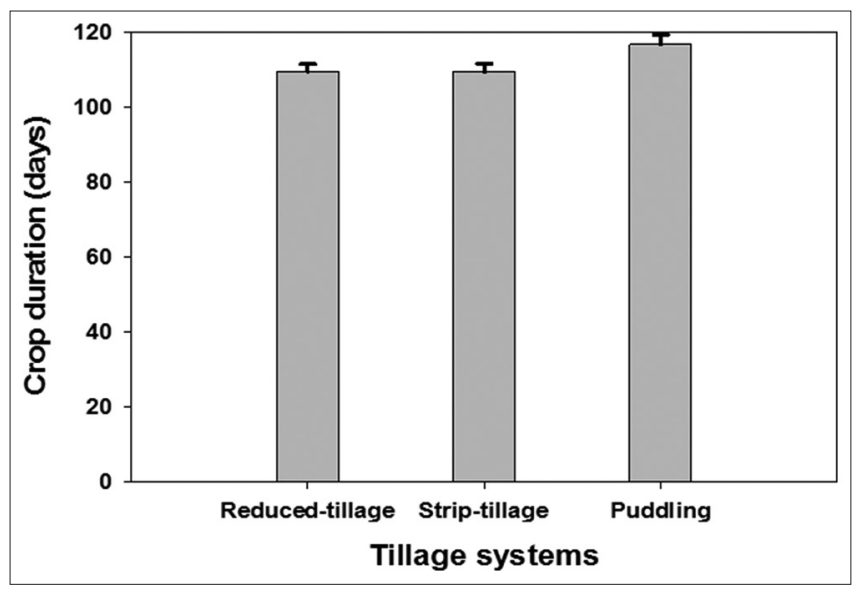

Figure 1: Effect of different tillage systems and crop establishment methods o crop duration

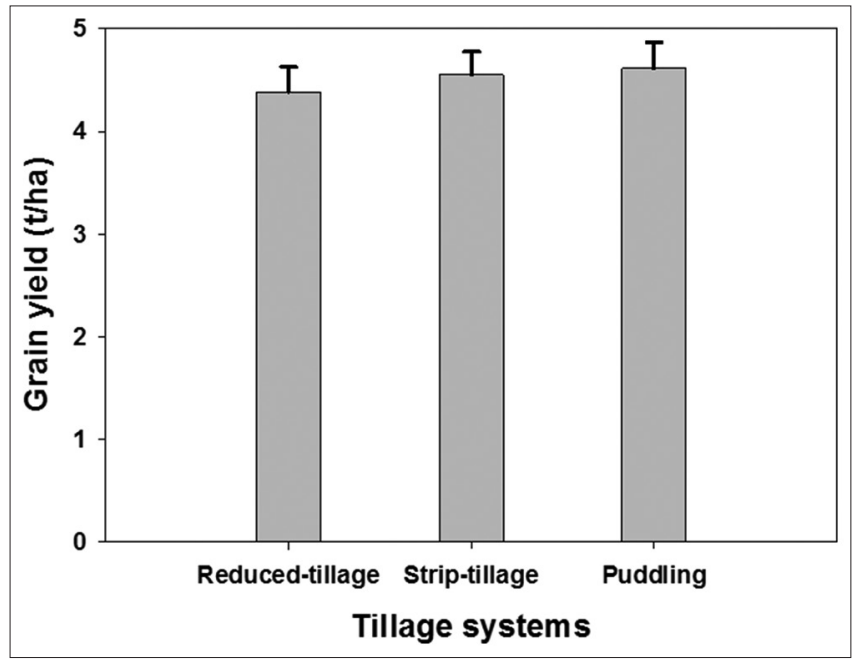

Figure 2: Effect of different tillage systems and crop establishment methods on grain yield

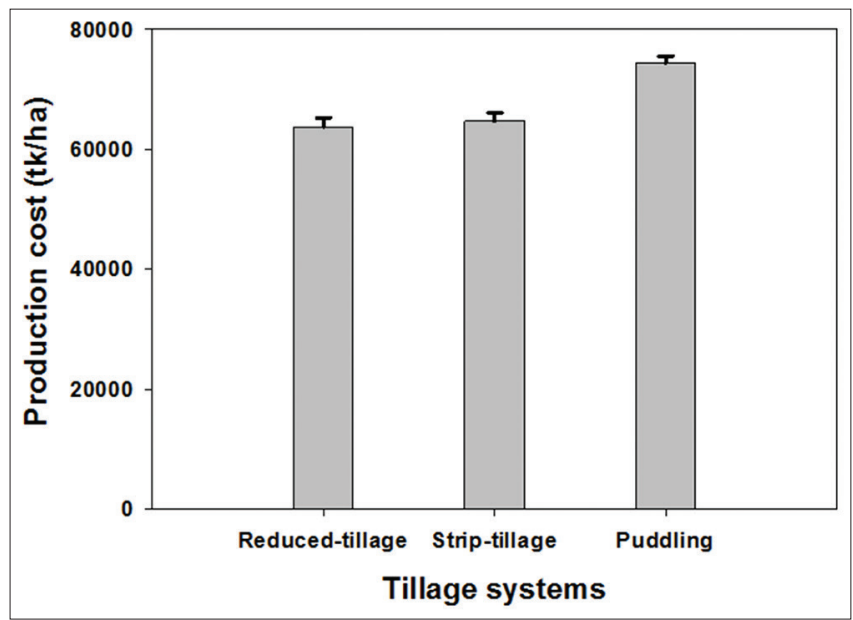

Figure 3: Effect of different tillage systems and crop establishment methods on total production cost

be a viable alternative to overcome the problem of labor and water shortage. If properly managed, comparable yield may 


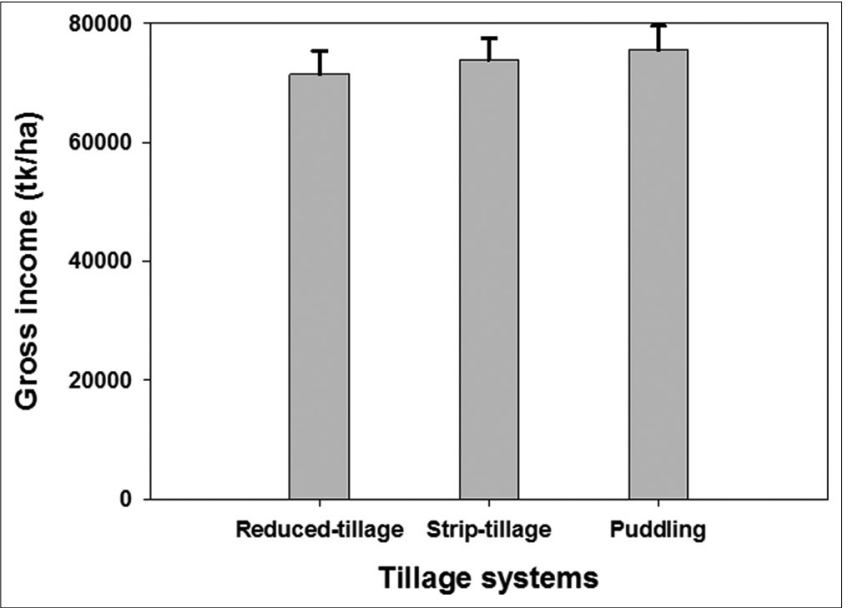

Figure 4: Gross income (taka ha ${ }^{-1}$ ) in different crop establishment methods

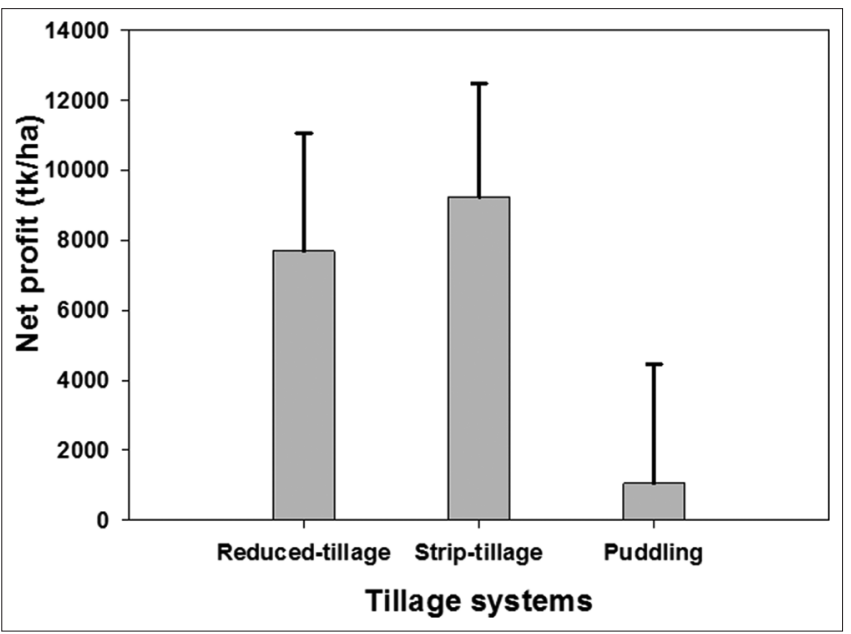

Figure 5: Net income (taka ha-1) in different crop establishment methods

be obtained DSR compared with the PTR. If not managed efficiently, weeds may cause partial to complete failure of DSR crops. Therefore, farmers' participatory on-farm evaluation of DSR should be undertaken at the different agro-ecological zones (AEZs) in Bangladesh; this should include rigorous determination of crop yields, gross margin, irrigation input, and farmer perceptions. Government programs to promote adoption of DSR systems are needed which may help to increase cropping intensity; this should include capacity building of farmers and the agricultural machinery sector.

\section{ACKNOWLEDGMENT}

We acknowledge the Cereal Systems Initiative for South Asia (CSISA, Bangladesh) and the Feed the Future (FtF) Rice Value Chains projects for providing the fund for conducting the trial. We thank AKM Ferdous for his excellent support during the trial period.

\section{REFERENCES}

1. Ahmed, S., Humphreys, E., Salim, M., Chauhan, B.S. Optimizing sowing management for short duration dry seeded aman rice on the High Ganges River Floodplain of Bangladesh. Field crops Research, 2014. 169: p. 77-88.

2. Alam, M.J., Humphreys, E., Sarkar, M.A.R., Yadav, S. Intensification and diversification increase land and water productivity and profitability of rice-based cropping systems on the High Ganges River Floodplain of Bangladesh. Field Crops Research, 2017. 209: p. 10-26.

3. Ahmed, S., and B.S. Chauhan. Performance of different herbicides in dry-seeded rice in Bangladesh. The Scientific World Journal, 2014 doi:10.1155/2014/729418: p. 1-14.

4. Chauhan, B.S., Ahmed, A., Awan, T.H., Jabran, K., Manalil, S. Integrated weed management approach to improve weed control efficiencies for sustainable rice production in dry-seeded systems. Crop Protection, 2015. 71: p. 19-24.

5. Ahmed, S., Humphreys, E., Chauhan, B.S. Optimum sowing date and cultivar duration of dry-seeded boro on the High Ganges River Floodplain of Bangladesh. Field Crops Research, 2016a. 190: p. 91-102.

6. Ahmed, S., Humphreys, E., Salim, M., Chauhan, B.S. Growth, yield and nitrogen use efficiency of dry-seeded rice as influenced by nitrogen and seed rates in Bangladesh. Field Crops Research, 2016b. 186: p. $18-31$

7. Hossain, M.S., Hossain, A. Sarkar, M.A.R. Jahiruddin, M. Teixeira da Silva, J.A., Hossain, M.I. Productivity and soil fertility of the rice-wheat system in the High Ganges River Floodplain of Bangladesh is influenced by the inclusion of legumes and manure. Agricultural Ecosystems and Environment, 2016. 218: p. 40-52.

8. Bhushan, L., Ladha, J.K., Gupta, R.K., Singh, S., Tirol-Padre, A., Saharawat, Y.S., Gathala, M., Pathak, H. Saving of water and labor in a rice-wheat system with no-tillage and direct seeding technologies. Agronomy Journal, 2007. 99:p. 1288-1296.

9. Sudhir-Yadav, Gill, G., Humphreys, E., Kukal, S.S., Walia, U.S. Effect of water management on dry seeded and puddled transplanted rice. Part 1: Crop performance. Field Crops Research, 2011. 120: p. 112-122.

10. Saharawat, Y.S., Singh, B., Malik, R.K., Ladha, J.K., Gathala, M., Jat, M.L., Kumar, V. Evaluation of alternative tillage and crop establishment methods in a rice-wheat rotation in North Western IGP. Field Crops Research, 2010. 116: p. 260-267.

11. Nie, L., Peng, S., Bouman, B.A.M., Huang, J., Cui, K., Visperas, R.M. Xiang, J. Alleviating soil sickness caused by aerobic mono-cropping: responses of aerobic rice to various nitrogen sources. Soil Science and Plant Nutrition, 2009. 55: p. 150-159.

12. Jokela, D., and A. Nair. Effects of reduced tillage and fertilizer application method on plant growth, yield, and soil health in organic bell pepper production. Soil and Tillage Research, 2016. 163: p. 243254.

13. Shekhawata, K., Rathorea, S.S., Kandpala, B.K., Premia, O.P., Singha, D., Chauhan, B.S. Crop establishment techniques affect productivity, sustainability, and soil health under mustard-based cropping systems of Indian semi-arid regions. Soil and Tillage Research, 2016. 158: p. 137-146.

14. Pandey, S., Suphanchaimat, N., Velasco, M.L. The patterns of spread and economics of a labor-saving innovation in rice production: the case of direct seeding in Northeast Thailand. Quarterly Journal of International Agriculture, 2012. 51 (4): p. 333-356.

15. Joshi, E., Kumar, D., Lal, B., Nepalia, V., Gautam, P., Vyas, A.K. Management of direct seeded rice for enhanced resource-use efficiency. Plant Knowledge Journal, 2013. 2: p. 119-134.

16. Kumar, A., Kumar, S., Dahiya, K., Kumar, S., Kumar, M. Productivity and economics of direct seeded rice (Oryza sativa L.). Journal of Applied and Natural Science, 2015. 7 (1): p. $410-416$

17. Mishra, A. K., Khanalb, A.R., Pedec, V.O. Is direct seeded rice a boon for economic performance? Empirical evidence from India. Food Policy, 2017. 73: p. 10-18.

18. Rashid MH, Alam MM, Khan MA, Ladha JK. Productivity and resource use of direct-(drum)-seeded and transplanted rice in puddled soils in rice-rice and rice-wheat ecosystems. Field Crops Research. 2009 Sep 4;113(3):274-81

19. Sarangi SK, Maji B, Singh S, Sharma DK, Burman D, Mandal S, Ismail AM. Haefele SM. Crop establishment and nutrient management for dry season (boro) rice in coastal areas. Agronomy Journal. 2014;106(6):2013-23. 